Eurasian Journal of Business and Economics 2018, 11(21), 23-48.

\title{
Performance of Women Entrepreneurs: Does Access to Finance Really Matter?
}

\author{
Abdul KHALEQUE* \\ Received: December 5, 2017 Revised: April 30, 2018 \\ Accepted: May 5, 2018.
}

\begin{abstract}
Bangladesh adopts labor intensive industrialization and inclusive finance strategy to fight against poverty. The strategies help the disadvantaged women empower and encourage doing something independently. But most of women entrepreneurs concentrated on major four types of businesses: parlor, boutique, clothing and fashion, which limit access to finance. The lack of access to finance was suspected to hamper their business growth. To understand such relationship, the descriptive as well as econometric tools and techniques were used. Durbin-Wu-Hausman test was used to test the endogeneity of the loan size. The test statistics suggest that the loan size is exogenous. Therefore, using the simple OLS method with various forms of error variances the regression results are estimated. Finally, the Feasible GLS method has been used to correct the heteroscedasticity problem. The result shows that the credit constraints and the credit size affect the monthly turnover of women entrepreneurs. The relaxation of credit constraint increases 6 percent monthly turnovers holding other things remaining same and so, it can be concluded that relaxing credit constraints improves business performance of women entrepreneurs.
\end{abstract}

Keywords: Credit, Entrepreneurship, SMEs, Turnover, and Women

JEL Code Classification: D21, H81, L20, L25, L26, M13

UDC: 331.445

DOI: https://doi.org/10.17015/ejbe.2018.021.02

\footnotetext{
Assistant Professor, Department of Development Studies, University of Dhaka, Bangladesh. Email: khalequedu02@gmail.com
} 


\section{Introduction}

Over the last two decades, the focus of development policy initiatives, especially policies aiming at reducing poverty has undergone significant changes. The initial shift started in the 90 s and led by the World Bank, poverty alleviation strategies started to gradually move from "poverty lending approach" towards a "financial systems" approach. Consequently, emphasis was placed on the development of the financial sector as a whole and this was a clear reflection of "getting institutions right" approach of the Post-Washington consensus (Gore, 2001; World Bank, 2001; Robinson, 2001). However, during the post-2000 era, many donors, especially those who have been active in the microfinance sector, though embraced the financial sector development approach, did not accept a complete abandonment of the poverty focus. In other words, focus of poverty reduction strategies shifted again and efforts were taken to develop an approach that would concentrate on the mainstream financial market while retaining a poverty focus (SIDA, 2003; DFID, 2005). Johnson (2013) explained the new development in the following way- "while the motivation can be seen in the original concerns... to get markets working, it is modified by the concerns for poverty reduction and the understanding that without adequate structured opportunities for the poor people, this recipe is set to increase inequality" (Johnson, 2013: 4). This particular approach which aimed at making markets work for the poor is mostly known as the "inclusive finance" agenda and explicitly focused on including the unbanked, disadvantaged, and the poor within the financial market. In addition to that, "inclusive finance" portrays a "Finance for All (FFA)" argument and aims at bringing the excluded population into the realm of mainstream banking, developing new schemes for ensuring a better access to financial services specially credits, and educating them about various financial products and services which may play an important role in taking informed decisions.

In the context of Bangladesh, this change of focus in development policy initiatives has already been felt. Whereas in the past, microfinance institutions had played the dominant role regarding the inclusion of the poor women in the financial sector, during the post-2000 period, significant efforts have been taken to initiate a broader approach for increasing the level and extent of financial inclusion of the poor into the mainstream banking sector. Consequently, emphasis has been placed on developing Small and Medium Enterprises (SMEs). This is not really surprising as in developing countries like Bangladesh; SMEs can be a vital player for poverty alleviation and rapid economic growth. At the same time, given that SMEs, in contrast to the self-employment approaches adopted by the Microfinance Institutions, can generate employment (Pagano \& Pica, 2012; De Nardi \& Villamil, 2009), mostly self-employment (Marlow \& Patton, 2005) and accelerate industrialization, they allow more opportunities for inclusive finance. As a result, over time a number of policy initiatives have been taken by the Government of 
Bangladesh and Bangladesh Bank to facilitate the growth of SMEs as an important vehicle of economic growth.

About half of the population of Bangladesh is women. Therefore, women's participation in the mainstream of the economy is crucial for attaining sustainable economic growth \& poverty reduction. But women participation in institutional economic sector is inadequate and the rate of women entrepreneurs is very low compared to that of male counterparts. In fact, there exist many obstacles in women participation in mainstream economy although the degree of integrity, devotion, creativity and expertise of women society make us surprised. Especially women participation in microcredit programmes and readymade garments industry is contributing significantly to the country's industrialization and poverty alleviation. Similarly, participation of women entrepreneurs in SME sector is playing a vital role for the flourishing of Bangladesh economy.

Bangladesh's approach towards inclusive finance is little different than the broader FFA policy agenda and whereas "inclusive financial markets approaches leaves gender and women's empowerment perspective outside the core of the debate", in Bangladesh, special efforts have been taken for including women within the financial market. Realizing that without ensuring women's participation and developing their entrepreneurial skills, a sustainable economic growth will not be possible, Bangladesh Bank, Ministry of Finance, Ministry of Industry and other authorities have designed detailed activities to achieve this goal. For instance, to ensure easier access to credit, Bangladesh Bank has circulated a directive that would allow the women entrepreneurs to receive loan at flat rate (i.e. bank rate $+5 \%)$. At the same time, Banks and financial institutions have been given the authority to give loan up to BDT 2,500,000 only with personal pledge if it is only female or female dominated business unit. Even though the extent of participation of the women entrepreneurs in the financial sector has not yet reached to a satisfactory level and they still suffer from a number of difficulties while gaining access to market, recent studies have indicated that these policy initiatives are gradually creating a business environment conducive to women's involvement in the SME sector.

Acknowledging the recent trend in development discourse and the important role played by the women entrepreneurs for the overall economic development of the country, the current study aims to identify the constraints, mostly the financial constraints, faced by the women entrepreneurs and the concurrent effects on business turnover.

\subsection{Research question and hypothesis}

The key research question is "are the women entrepreneurs constrained by financial factors?" and "are those constraints hinder the sales performance of the enterprises?" From the common sense view, we perceive that women, in general, are constrained by social, economic, and political factors but we have limited 
information on their extent and their likely impacts on business development. Considering the recent initiatives for promoting women entrepreneurships, let us hypothesize that the access to finance has no significant effect on entrepreneurs and entrepreneurial activities, i.e., the access to finance has no effect on sales and capital formation. The alternative hypothesis, therefore, will presume the orthodox believe that the access to finance is helpful in promoting women entrepreneurship through enhancing sales and capital formation.

\section{Literature Review}

Entrepreneurship is a major contributing factor to economic growth and poverty alleviation (King \& McGrath, 1999; Siddiqui, 2003; Bruton et al., 2013; Gielnik \& Frese, 2013; Mulira et al., 2011; Servon \& Bates, 1998) both in rural and urban areas. Enterprises are called the "engine of growth" (Francis et al., 2013). At macro level, it is well-established that finance matters for growth (Levine, 2003, 2005; King \& Levine, 1993; Cecchetti \& Kharroubi, 2012; Deidda \& Fattouh, 2002; Demirgüç-Kunt et al., 2008; Harrison et al., 1999). At micro level, similar relationship exists. Guariglia et al. (2011) argued that liquidity constraints affect firms' assets growth. In case of binding credit constraint, the internal finance can help the firm to grow (Carpenter \& Petersen, 2002). Hence, external finance contributes in firms' growth (Becchetti \& Trovato, 2002; Ang, 2008; Cull \& Xu, 2005; Beck et al., 2004). The reverse of finance-growth nexus is found in credit-constraint and growth relationship (Manova, 2013). Credit constraints not only impedes investment and growth (Minetti \& Zhu, 2011; Binks \& Ennew, 1996) but also deters in entry and forces to leave during bad period (Aghion, Fally \& Scarpetta, 2007; Musso \& Schiavo 2008). In international setting, credit constraint reduces firm's exports (Muûls, 2008; Minetti \& Zhu, 2011). The firm has a productivity loss due to credit constraint (Banerjee \& Duflo, 2008).

The women are relatively more credit constrained than men (Khaleque \& Eusuf, 2015) and they are discriminated in every stage. Therefore, credit constraint has a double effect on women led enterprises. However, training, education, and business experience can relax the credit constraint to a great extent. The performance of women entrepreneurs or the starting of new business is significantly influenced by entrepreneurial intention which is also influenced by personal attitude and behavioral control (Dinc \& Budic, 2016). The study of Celebioglu (2017) shows that gender inequality affects the women employment.

\subsection{Women Entrepreneurs and Access to Finance in Bangladesh}

During 2010 to 2015, around 320,547 women entrepreneurs received 17,594 crore taka in total, on an average, 550,000 taka per women entrepreneurs. In 2015, 188,233 women entrepreneurs received a total credit of 4,227 crore taka and 4,300 women entrepreneurs received credit without collateral. The number of credit receiving women entrepreneur increased by 340 per cent (Bangladesh Bank, SME Department, 2016). 
Performance of Women Entrepreneurs: Does Access to Finance Really Matter?

Table 1. SME, Women Entrepreneurs and Credit Disbursement

\begin{tabular}{|c|c|c|c|c|c|c|}
\hline Year & $\begin{array}{c}\text { Number of } \\
\text { entrepreneurs }\end{array}$ & $\begin{array}{l}\text { Amount } \\
\text { of Credit } \\
\text { (Crore) }\end{array}$ & $\begin{array}{c}\text { Number of } \\
\text { entrepreneurs }\end{array}$ & $\begin{array}{c}\text { Amount of } \\
\text { Credit } \\
\text { (Crore) }\end{array}$ & $\begin{array}{c}\text { Women } \\
\text { Entrepreneurs } \\
\text { as \% of SME }\end{array}$ & $\begin{array}{l}\text { Credit for Women } \\
\text { Entrepreneurs as per } \\
\text { cent of all SME credit }\end{array}$ \\
\hline 2010 & 308,950 & $53,543.9$ & 13,831 & $1,804.98$ & $4.48 \%$ & $3.37 \%$ \\
\hline 2011 & 319,340 & $53,719.4$ & 16,696 & $2,048.45$ & $5.23 \%$ & $3.81 \%$ \\
\hline 2012 & 462,513 & $69,753.4$ & 17,362 & $2,244.01$ & $3.75 \%$ & $3.22 \%$ \\
\hline 2013 & 744,228 & $85,323.3$ & 41,695 & $3,346.55$ & $5.60 \%$ & $3.92 \%$ \\
\hline 2014 & 541,656 & $100,910.2$ & 42,730 & $3,938.75$ & $7.89 \%$ & $3.90 \%$ \\
\hline 2015 & 724,903 & $115,870.5$ & 188,233 & $4,226.99$ & $25.97 \%$ & $3.65 \%$ \\
\hline
\end{tabular}

Source: Bangladesh Bank, SME Department

The statistics show that there are remarkable increase in the number of women entrepreneurs as per cent of SME but share of women's credit to SME credit remains low and to be real, the share has declined compared to 2014.

\section{Conceptual Framework}

Conceptually, the term "entrepreneur" refers to a person who starts, organizes and manages any enterprise usually with considerable initiative and risk for profit motives whereas entrepreneurship refers to the process of designing, launching and running the business. Women entrepreneur or women entrepreneurship, therefore, simply refers to the gender dimension of ownership and managing the enterprise. According to Bangladesh Bank definition, if a woman is the sole owner or proprietor of any concern or partner in any partnership firm or director in any private company registered with the Joint Stock Company owns minimum 51\% shareholdings of the company, she can then be considered to a woman entrepreneur.

The financial perspective deals with the concept "access to finance". Access to finance refers the incumbent applicant can have easy and available access to credit, saving and insurance services. Therefore, the eligible women entrepreneurs who perceive and who accessed the credit service from financial institution are said to have access to finance.

The women entrepreneurship development is an issue that has many dimensions. Anwar and Rashid based on literature review tried to build a model of entrepreneurship in aiming to encapsulate the essence of female entrepreneurs (see figure 1).

The model of women entrepreneurs gives us the comprehensive view of developing women entrepreneurs. A set of diverse factors motivates the women to be an entrepreneur: push-pull (Stevenson, 1986; Itani et al., 2011), personal attribute like leadership (Dzisi, 2008), social factor like family kinship (Jamali, 2009) and aspiration of better standard of living (Nadgrodkiewicz, 2011). Besides the personal motivations, some local and international level institutions proactively support for the development of women entrepreneurs like the effective 
governmental planning and strategies to promote women entrepreneurs (De Bruin et al., 2007; Itani et al., 2011) through the support programs (Farr-Wharton \& Brunetto, 2007), NGO-MFIs (Mustafa \& Ismailov, 2008), international organizations like AUSAID, UKAID, etc., and competitive financial institutions (McLymont, 2008).

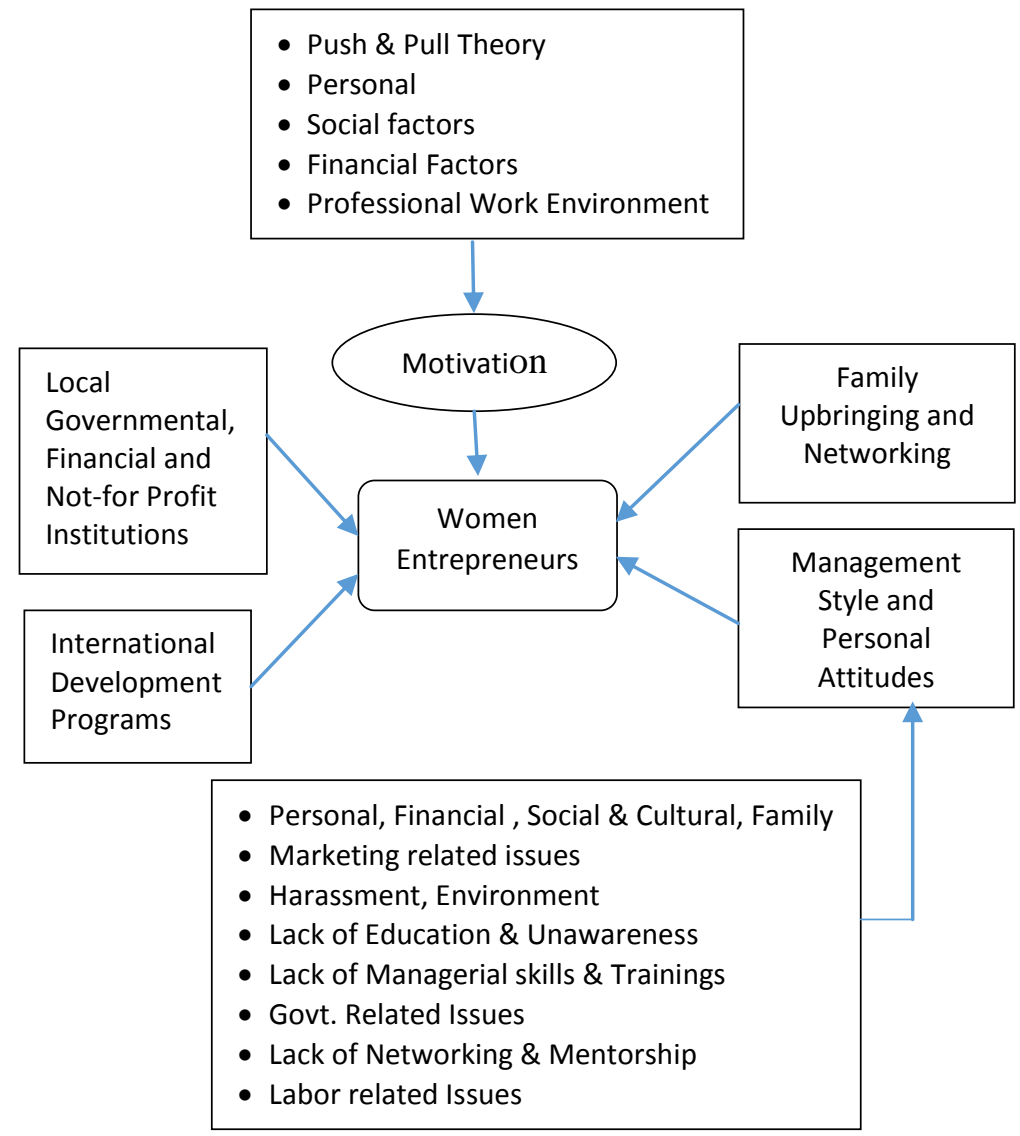

Figure 1. Model of women entrepreneurs

Source: Adapted from Anwar and Rashid (2012)

However, the development of women entrepreneur is not as much promising as the model of women entrepreneurs suggests. Women entrepreneurs suffer from a set of diverse constraints like financial constraint (Halkias et al., 2011) or credit constraint in financial institutions (Roomi et al., 2009) and non-financial barriers.

The broader constraints faced by a woman entrepreneur can be of two types: financial and non-financial. The constraints can be faced at various stages of the business like at the beginning of the business or during the phase of business growth. The incumbent constraints are likely to have effect on business performance of the women entrepreneurs. 


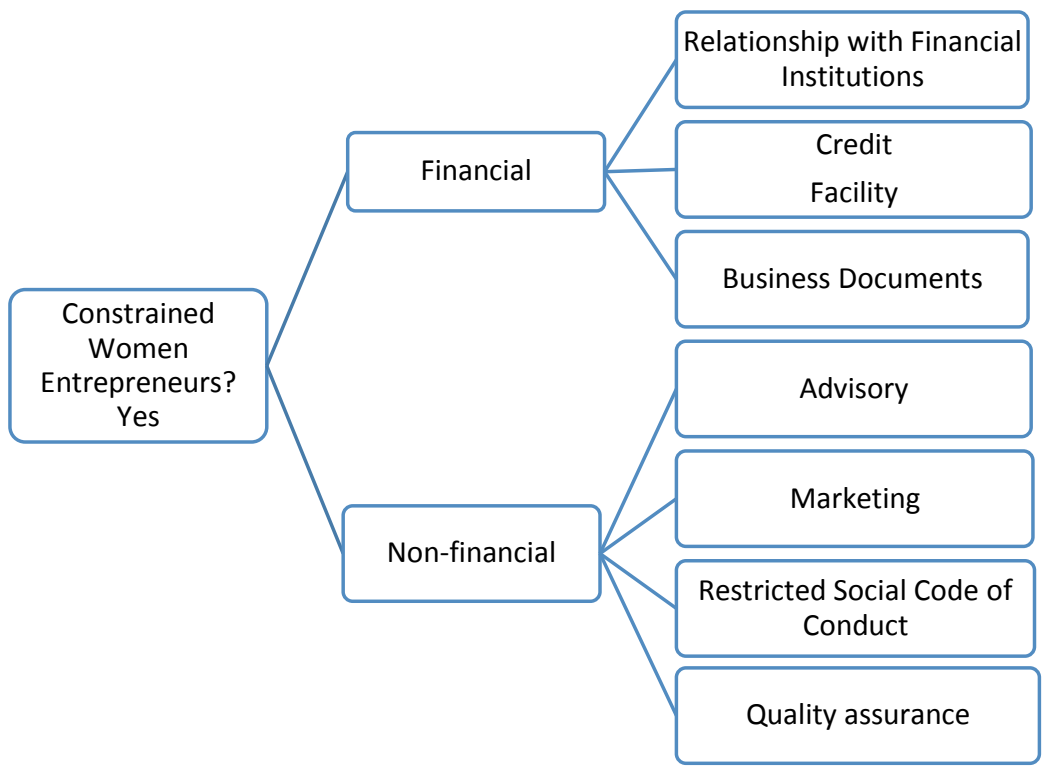

Figure 2. Conceptual framework of constraints faced by the women entrepreneurs

Source: Author (2016)

The social and non-financial constraints can create barriers against the entry of potential women entrepreneurs. But financial constraints have effects on business start-up phase, business growth phase, and, overall, business performance. Although the financial constraints for women entrepreneurs have demand and supply side explanation (see Fay \& Williams, 1991; Carter \& Rose, 1998; Carter, 2000; Carter et al., 2003), it has implications for business performance in general.

\section{Theoretical Framework}

Although the primary objective of a woman entrepreneur, like other entrepreneurs, is to maximize profit; but through capital formation, bringing the business in the centre of growth periphery is also an important motto of women entrepreneur. A larger capital accumulation will help to move in the front and the center of growth. But hindrances toward business growth and capital formation can reduce the space for development. The entrepreneurs must have sufficient working capital to run the business efficiently and profitably.

\subsection{The Model}

For understanding the theoretical relationship between working capital shortage and financial constraint is being modeled following Chan (2010) which is partial equilibrium model designed to isolate dynamic responses of the firm to output price or productivity shocks. 
The fundamental problem firm is to maximize the present value of profits over an infinite horizon and, thereby, the maximization problem becomes as follows:

$$
\begin{aligned}
& \max _{L_{t}, K_{t}} E_{t}\left[\sum_{t=0}^{\infty} \beta^{t}\left(\beta P_{t} F\left(K_{t}, L_{t}\right)-w L_{t}-P^{k} I_{t}\right)\right] \\
& \text { s.t } \quad w L_{t}+P^{k} I_{t}+b_{t}=P_{t-1} F\left(K_{t-1}, L_{t-1}\right)+(1+r) b_{t-1} \\
& \text { s.t } \quad K_{t+1}=(1-\delta) K_{t}+I_{t} \\
& \text { s. } t \quad b_{t} \geq b c \\
& \lim _{n \rightarrow \infty} b_{t}=0 \\
& K_{o} \text { and } b_{o} \text { are given }
\end{aligned}
$$

This preceding setup follows the standard dynamic model except for the delay in revenues. Production requires at least two fundamental inputs: capital and labor. Capital, a durable factor bringing a future stream of benefits, evolves according to equation (3). The term $\delta$ refers depreciation rate which is assumed to be less than one and time invariant. Labor, a short-term variable input, is assumed perfectly elastically supplied. Other inputs as well can be in the production process. In every period, the firm chooses inputs to maximize the stream of expected profits satisfying the budget constraint given by equation (2), where the term $b$ refers to bond holdings. The discount factor of $b$ is assumed to be equal to $\frac{1}{1+r}$. The price of investment, $P^{k}$, the wage, $\mathrm{w}$, and the interest rate $r$ are exogenous and time invariant.

Working capital is essentially assumed to be a one-period delay in revenue receipt and so, the firm's profit discounts the revenue by one period. The budget constraint, equation (2), includes the revenue from last period's production and internally generated funds. The borrowing constraint $b c$ is introduced as an exogenous parameter ranging from negative to positive number including zero. Capital has no adjustment costs and requires no time to install. Capital stock can be re-sold at the prevailing market price. Thus, physical capital is assumed to be a liquid asset. Firms can transfer financial resources across time through bonds or capital assets.

The $P_{t}$ refers output price. The changing factors of value of output is the only stochastic variable, where $P_{t}=\bar{P}+\varepsilon_{t}$ and $\varepsilon \sim\left(0, \sigma_{\varepsilon}^{2}\right)$ and is i.i.d. The firm has certainty of output price information before making input decisions, just like; the firm is receiving orders for its product and signing contracts that set the price it will receive upon delivery of the order. But price is uncertainty in future years. Cash in hand is defined as the sum of revenue and bond holdings, $X_{t}=P_{t-1} F\left(K_{t-1}, L_{t-1}\right)+(1+r) b_{t-1}$.

The budget constraint includes the cash in hand and all forms of liquid able financial resources that yields the transition equation of wealth over time: $X_{t-1}=$ $(1+r)\left[X_{t}-w_{t} L_{t}-P^{k} I_{t}+P_{t} F\left(K_{t}, L_{t}\right)\right]$. The cash in hand describes all of the 
financial resources available to the firm. The state variables are capital stock, $K_{t-1}$, and cash in hand, $X_{t}$. Control variables labor and capital are denoted as $L_{t}$ and $K_{t}$. To solve the problem, following Chen (2010) let us form the associated Bellman equation as follows:

$$
\begin{array}{r}
V\left(X, K_{-1}\right)=\max _{L, K} \beta P(\varepsilon) F(K, L)-w L-P^{k}\left(K-(1-\delta) K_{-1}\right)+\beta E V\left(X^{\prime}, K\right) \\
\text { s.t. } \quad X^{\prime}=P(\varepsilon) F(K, L)+(1+r)\left[X-P^{k}\left(K-(1-\delta) K_{-1}\right]\right. \\
\quad \text { s.t. } \quad X-w L-P^{k}\left(K-(1-\delta) K_{-1}\right) \geq b c
\end{array}
$$

With the multiplier in the borrowing constraint, $v^{b}$, the first order condition becomes:

$$
\begin{aligned}
& \left(\beta P F_{L}(K, L)-w\right)\left(1+E\left[\frac{\partial V\left(x^{\prime}, P^{\prime}\right)}{\partial x^{\prime}}\right]\right)=w v^{b} \\
& \beta P F_{K}(K, L)-P^{k}+\beta P^{k}(1-\delta)\left(1+E\left[\frac{\partial V\left(x^{\prime}, P^{\prime}\right)}{\partial x^{\prime}}\right]\right)=P^{k} v^{b}
\end{aligned}
$$

Equation (6) and (7) show that the firm weighs the future value of cash $(1+$ $E \partial V x^{\prime}, P^{\prime} \partial x^{\prime}$ against the shadow value of loosening the current period's borrowing constraint, $v^{b}$, in its choice of factors. The solution of the problem now becomes:

\section{Table 1. Conditions of optimal solution of factors}

\begin{tabular}{lcc}
\hline \multicolumn{2}{c}{ Unconstrained firm $\left(v^{b}=0\right)$} & \multicolumn{2}{c}{ Constrained firm $\left(v^{b} \neq 0\right)$} \\
\hline$\beta P F_{L}(K, L)=w$ & (8) & $\frac{\beta P F_{L}(K, L)}{w}=\frac{\beta P F_{K}(K, L)}{P^{k}}+\left(\frac{1-\delta}{1+r}\right)$ \\
$\beta P F_{K}(K, L)=P^{k}\left(\frac{r+\delta}{1+r}\right)$ & (9) & $X=w L+P^{k}\left(K-(1-\delta) K_{-1}\right)+b c$
\end{tabular}

If the firm faces a binding constraint, then it can't achieve the optimal production which is presumed to be achievable under free optimization and so reaches constrained optimum. In constrained optimization, the firm's output and profit is generally low. The firm needs to consider the expected benefits of cash the next period, $\left(1+E\left[\frac{\partial V\left(x^{\prime}, P^{\prime}\right)}{\partial x^{\prime}}\right]\right)$, along with the cost of binding constraints today, $v^{b}$, when making factor input choices. As both the future benefit of cash and the present shadow value of cash enter the two first order conditions, equations (6) and (7), the ratio of the two conditions yields:

$$
\frac{\left(\beta P F_{L}(K, L)-w\right)}{w}=\frac{\beta P F_{K}(K, L)-P^{k}+\beta P^{k}(1-\delta)}{P^{k}}
$$

It is noted that even though the firm is optimizing dynamically, the forward looking terms cancel out and current actions can be described independently of expectations, which yields an analytically tractable solution. Under constraints, the firm need only compare the present opportunity cost of funds, $w$ and $P^{k}$, and the relative returns, $\left(\beta P F_{L}(K, L)-w\right)$ and $\beta P F_{K}(K, L)-P^{k}+\beta P^{k}(1-\delta)$, between 
the two factors. The relative returns, that are the factor returns net of cost, are greater the further away factors are from optimal levels.

Relative returns: $\left(\beta P F_{L}(K, L)-w\right)$ and $\beta P F_{K}(K, L)-P^{k}+\beta P^{k}(1-\delta)$

Therefore, the constrained output is a function of external parameters, working capital $X$, and borrowing constraint $b c$. Thus,

$Y_{i}^{f c}=g\left(P, p^{k}, r, \delta, w, \alpha, \gamma X, b c\right)$

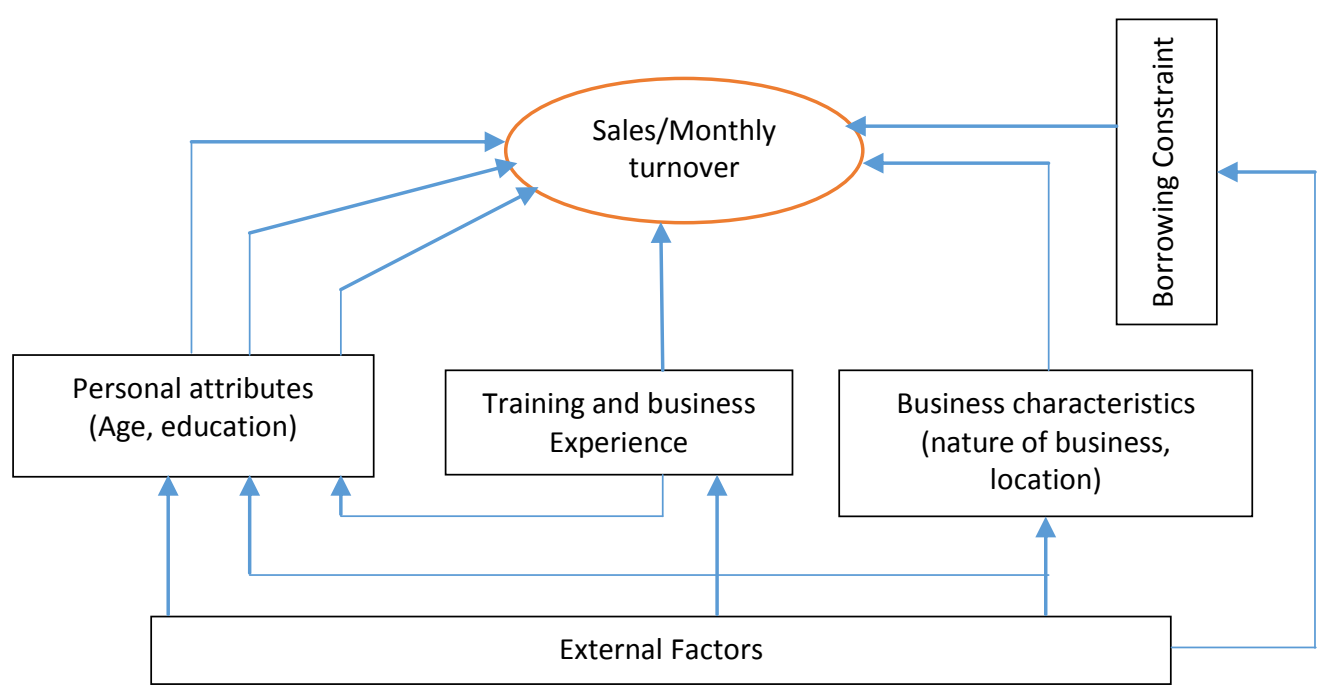

Figure 3. Theoretical Framework

\section{Empirical Strategy - Econometric Model Specification}

Access to finance and size of finance are determined by a set of exogenous variables, for example, characteristics of the entrepreneurs, characteristics of business, and some socio-economic condition like the characteristics of the household to which the entrepreneur belongs to, the supply-side factors and some regional characteristics. Based on this, the access to finance, measured by the amount of loan received, can be modeled as follows:

$$
\log C=\alpha X+\varepsilon_{1}
$$

Here, $\alpha$ is the set vector of coefficients of the exogenous variables, $X$, including a constant term; $\varepsilon$ is the stochastic error term which is assumed to satisfy the assumptions of classical linear regression model.

The sales of the enterprises which has sufficient working capital to generate the output and maintain the business operation can be modeled as follows: 


$$
\log Y_{i}=\beta Z+\varepsilon_{2}
$$

For the enterprises which has fund constraints or working capital shortage, i.e., the output or sales of the enterprise depends on external cash flow especially the credit support, then the sales model becomes as follows:

$$
\log Y_{i}=\beta X+\gamma \log C+\epsilon
$$

Here, $\log Y_{i}$ denotes monthly turnover of the firm or the accumulated capital size; $\beta$ is the vector of coefficients of external exogenous variables $(X) ; C$ is a continuous variable containing value 1 for an enterprise having no access to credit and greater than 1 value for those who have access to finance; $\gamma$ is the coefficient of access to finance or the financial unconstraint; $\in$ is the stochastic disturbance term which is presumed to be normally and independently distributed with mean 0 and variance $\sigma_{\epsilon}^{2}$.

The model (17) represents the theoretical specification of the effects of financial constraint on sales or capital formation. Since the model (17) is just a composite version of model (15) and model (16), the model is suspected to encounter the endogeneity problem. If endogeneity problem exists, the OLS estimates of model (17) will be inconsistent. In that case, the instrumental variable technique can help us to derive the consistent estimates.

To test the endogeneity, we are proposing to use the two techniques: (i) the regression based Durbin-Wu-Hausman test (Wu, 1974; and Hausman, 1978), and (ii) Single-equation instrumental-variables regression techniques.

\subsection{Research Methods}

The current study follows the mixed method - the integration of qualitative and quantitative research techniques - to answer the research questions and to fulfill the stated research objectives. The sample women entrepreneurs, on which the findings are generalized, have been be drawn from six districts of six divisions of the country except Dhaka. To understand the issue of access to finance for women entrepreneurs from supply sides, interviews of managers and SME loan officers of some branches of private banks have also been conducted in the study areas and interviews of dedicated officers and high officials of Bangladesh Bank have been conducted in the study areas to understand the views and process of relaxing credit constraints for women entrepreneurs. The sample women entrepreneurs have been interviewed through structured questionnaires and the interviews of management of private banks and Bangladesh Bank have been through checklists.

A purposive sampling techniques has been followed in the study. The primary sampling units, Sadar Upazila of Divisional District, and the secondary sampling units, the women entrepreneurs, have been selected from the pool of women entrepreneurs who are the members of women entrepreneurs' organization like Women Chamber, Women Business Forum etc. The institutions like bank branch 
and Bangladesh Bank branches have been selected on convenience and local perception bases.

As the survey areas, six divisional districts Barisal, Chittagong, Khulna, Rajshahi, Rangpur, and Sylhet are selected for sampling purpose. From the sampled districts the Sadar Upazila has been considered as the survey areas. The secondary sampling units have been randomly selected from the pool of women entrepreneurs of different organization of women entrepreneurs. From the selected Sadar Upazilas of the six divisional districts, the project areas, at best 50 samples have been selected from the members of women entrepreneurs led organization. The sample women, therefore, are women entrepreneurs. There are 168 sample women entrepreneurs in study.

The survey was conducted through structured questionnaires for women entrepreneurs and through checklists for bank officials, and through open-end discussion questions with the Bangladesh bank officials. The questionnaires have been pre-tested by interviewing some women entrepreneurs. Based on the literatures and discussions with women entrepreneurs, the regulators and experts and experiences of the field testing, questionnaires have been finalized for conducting the survey. The questionnaire contains several sections like preliminary information about the business such as business type, business location and acquisition of various business related licenses, problems in the business at the early stage of establishment, and problems during the escalation or growth periods. Finally, the extent of access to finance, measured by access to account (savings/loan), is expected to be assessed through the questionnaire.

\section{Findings}

Understanding the relationship between business performance and credit constraint requires the understanding the characteristics of the firm. Therefore, the analysis follows a descriptive approach, a description of the characteristics of women entrepreneurs including their business characteristics. Finally, the relationship between business performance and credit constraint is being tested within the sophisticated econometric techniques.

\subsection{Characteristics of Women Entrepreneurs}

The women entrepreneurs have some distinct characteristics. The current study shows that only 8.8 per cent women entrepreneurs has age up to 20 years and around 35 per cent of women entrepreneurs are over 40 years old. The average and median age of women entrepreneurs are estimated at around 35 years while the modal age is 40 years. The coefficient of variation of age of women entrepreneurs shows that the age distribution of women entrepreneurs is quite normal.

The women entrepreneurs are mostly educated. The study shows that over 88 per cent of women entrepreneurs has education level over grade 9 and around 12 per 
cent has education below SSC. Around 41.3 per cent women entrepreneurs have completed higher educations - honors/masters. The average schooling of women entrepreneurs is 12. But earlier studies shows that most of the women entrepreneurs $(60 \%)$ started their business at their teenage, around 75 per cent belonged to the age brackets of 30-45 (Saleh 1995), and average age was 40.6 years (Abdullah, 1996) and 90 per cent of them have education level less than SSC (Nabi \& Salahuddin, 1989). The age-experience and education level, the human capital, of women entrepreneurs have increased.

Ownership matters for empowering the women. The current study shows that almost 85 per cent of the women enterprises are sole entrepreneurs and only 15 per cent are partnerships - partnership with family members are 7 per cent and partnership with non-family members are around 8 percent. Among the women entrepreneurs, around 83 per cent are married and only 18 per cent are unmarried. Of the married women entrepreneurs, around 58 per cent of their husband is businessman and around 35 per cent are service holders. Only 8 per cent of their husbands are engaged in other activities. Overall, 65 per cent women entrepreneurs claim that they lead their household. Their claim could be justified if we look at their previous occupation. Before being the entrepreneurs, around 61.5 per cent of women entrepreneurs were housewife only and 20 per cent were students.

According to BWCCl (2011) women entrepreneurs are mostly engaged in manufacturing and trading (41.6 per cent) and limitedly in exporting (10.6 per cent). The whole sellers and retailers are 6.2 per cent and 13 per cent respectively. Around 13 per cent women entrepreneurs are engaged in service sectors.

\subsection{Business Start-up and Growth Phase - The Underlying Factors}

Starting a business, an opportunity of self-employment, is not at point decision, rather various factors contributes in promoting business and business development. Women entreprenMoeurs start their business not because of availability of credit but because of their own experiences. For example, around 36 per cent women told that they started their business due to their family business experience and 11 per cent has said that their previous job experience has helped them to start their business. Training institutes and financial institutes induced around 13 percent women to start the business. The business success of other women also forces the women to start a new business: around 28 per cent agreed upon this statement.

The experiences from family businesses or their previous jobs or the inducement of various institutions have induced the women entrepreneurs to do some independent economic activity (49 per cent) and to solvent their family as well as the entrepreneur herself (49 per cent). 
The business of women can be said in-house business as around 66.5 per cent of the women run their businesses using their home as the business outlet and 31 per cent have business outlets in commercial places like local market place.

Around 53 per cent women entrepreneurs have parlor or boutiques business and around 21 per cent have tailoring or fashion related business. Therefore, near about three-fourth of the women entrepreneurs are employed in major four activities: (i) parlor, (ii) boutiques, (iii) tailoring, and (iv) fashion. In a broad category, women entrepreneurs are engaged with business related to parlor and cloth items - boutiques or fashion.

The initial and current capital structure of the neophyte women entrepreneur is almost same whereas the current capital size increased around 3 fold for women entrepreneurs having business experience of 3 to five years. We observe that capital size intensifies with level of experience which is expected as overtime the capital size aggrandizes (table 2 ).

\section{Table 2. Capital structure}

\begin{tabular}{cccc}
\hline Business experience & Initial Capital & Current Capital & Ratio of current capital to initial capital \\
\hline $0-2$ & 62810 & 66292 & 1.06 \\
$3-5$ & 49826 & 156731 & 3.15 \\
$6-9$ & 214939 & 372420 & 1.73 \\
$10-15$ & 198679 & 735001 & 3.70 \\
$16-20$ & 230750 & 1069378 & 4.63 \\
Above 20 & 82521 & 1429167 & 17.32 \\
\hline Average & & & \\
\hline 8 Years & 124589 & 2278359 & 18.3 \\
\hline
\end{tabular}

Source: Survey Data (2016)

The initial capital structure for the experienced women entrepreneur has increased more compared to the new entrepreneur. The average business experience is estimated at 8 years. The average initial capital was 124,589 taka which increased to $2,278,359$ taka.

Most of women entrepreneurs starts their business with a one or two male labor and over three female labor. Overall, the average employment in women enterprises is six. The average employment size almost becomes tripled, near about 210 percent growth of employment size, and the growth of employment size is not uniform across districts (table 3 ).

The average monthly turnover in Barisal district is the lowest and the second lowest turnover is in Rangpur. These two districts have annual median turnover below one lac. In Chittagong and Sylhet, the annual median sale is 0.78 million and 1.2 million respectively. In other districts, the monthly turnover lies in between 0.24 million to 0.78 million. Near about 81 per cent women entrepreneur possesses trade license and 48 per cent women entrepreneur has own business TIN certificate. Around one-fifth of the women entrepreneur holds personal TIN and 
VAT certificates. Among the experienced women entrepreneur the possession of various business related license and certificates is high compared to the neophyte women entrepreneur (table 4).

Table 3. Employment structure

\begin{tabular}{ccccccc}
\hline & & Initial & & & Current & \\
Experience Category & Male & Female & Total & Male & Female & Total \\
\hline $0-2$ & 0.54 & 2.50 & 2.60 & 2.43 & 2.23 & 4.07 \\
$3-5$ & 0.75 & 3.13 & 3.88 & 3.04 & 3.05 & 5.71 \\
$6-9$ & 1.00 & 4.72 & 5.30 & 6.63 & 7.89 & 12.19 \\
$10-15$ & 1.60 & 4.45 & 5.91 & 24.18 & 4.27 & 27.09 \\
$16-20$ & 2.64 & 12.45 & 15.09 & 17.82 & 22.88 & 34.45 \\
Above 20 & 0.56 & 5.11 & 5.67 & 17.00 & 16.86 & 30.11 \\
Overall & 2 & 5 & 6 & 7 & 12 & 19 \\
\hline
\end{tabular}

Source: Survey Data (2016)

Table 4. Monthly turnover

\begin{tabular}{cccccccc}
\hline \multirow{2}{*}{$\begin{array}{c}\text { Experience } \\
\text { Category }\end{array}$} & \multicolumn{3}{c}{ Monthly turnover } & \multicolumn{4}{c}{ Business Formalities } \\
\cline { 2 - 8 } & Average & SE & Median & $\begin{array}{c}\text { Trade } \\
\text { License }\end{array}$ & $\begin{array}{c}\text { Business } \\
\text { TIN }\end{array}$ & $\begin{array}{c}\text { Personal } \\
\text { TIN }\end{array}$ & $\begin{array}{c}\text { VAT } \\
\text { Certificate }\end{array}$ \\
\hline $0-2$ & 30861 & 10902.57 & 12500 & 64.00 & 24.00 & 2.00 & 6.00 \\
$3-5$ & 94333 & 37322.41 & 25000 & 92.00 & 56.00 & 8.00 & 16.00 \\
$6-9$ & 54655 & 15191.66 & 25000 & 83.33 & 56.67 & 23.33 & 16.67 \\
$10-15$ & 456818 & 360036.7 & 45000 & 81.48 & 44.44 & 33.33 & 37.04 \\
$16-20$ & 694786 & 430250.9 & 125000 & 100.00 & 78.57 & 42.86 & 35.71 \\
Above 20 & 1404167 & 854937.1 & 100000 & 100.00 & 78.57 & 57.14 & 57.14 \\
Total & 285004 & 100012.8 & 25000 & 81.25 & 48.13 & 20.63 & 21.88 \\
\hline
\end{tabular}

Source: Survey Data (2016)

\subsection{Business Start-up: Process, Finance, and Problems}

We know that women have engaged in economic activity with a view to doing something independently which is expected to empower them. They have mostly gathered business experience from their father/mother/brothers or from the experience of other businesses. But starting the business was not challenge free. The business start-up related constraints are presented in the following figure.

Our cultural context sometimes does not encourage women to be engaged in independent economic activity. The women entrepreneurs first face the constraints at their own house or at their society where they live and the constraints are mostly created by their own relatives/own society. Of the survey women respondents, 26 percent reported that social hindrance is an important factor that bars the women entrepreneurs to start a new enterprise. Alongside, 20 percent of the women entrepreneurs said that family hindrance has also impeded their business start-up plans (figure 4).

Business related formalities like trade license, TIN (business/personal), and other relevant certificate have played negative role in promoting women 
entrepreneurship. But the problem is not much acute now. Only 8.75 of the respondents considered lack of trade license as a barrier of starting new business.

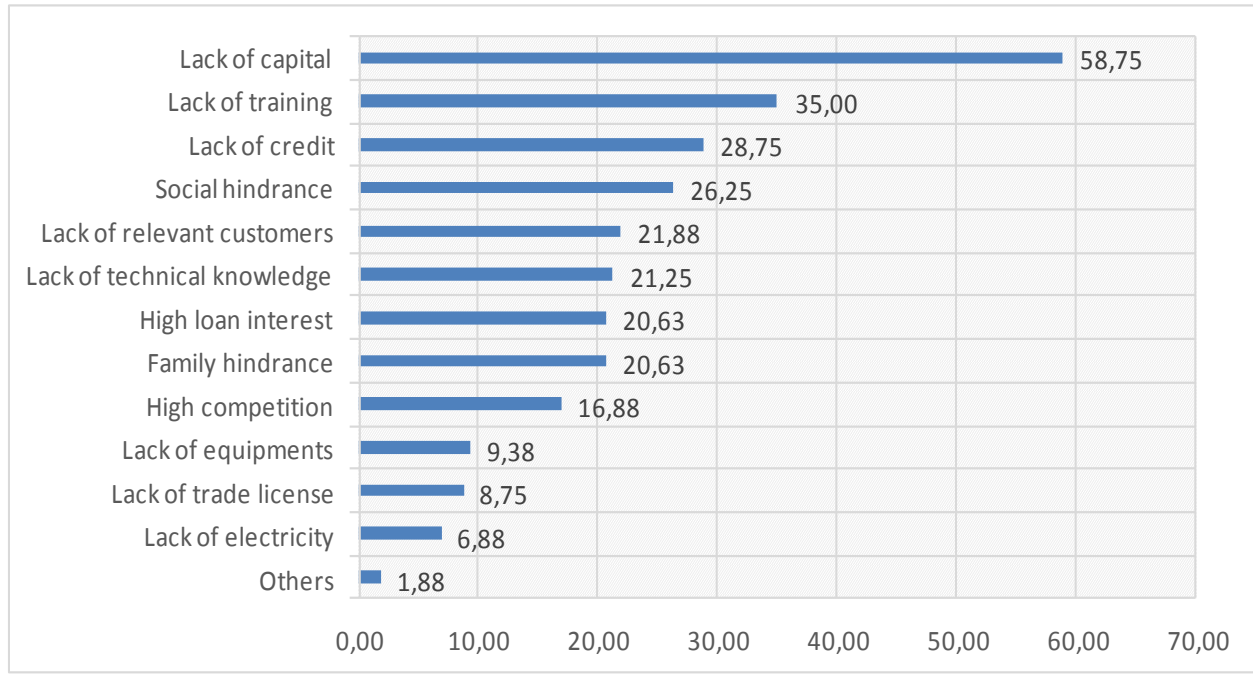

Figure 4. Business start-up constraints

Source: Survey Data (2016)

The lack of supply of relevant inputs for business sometimes hinders the business initiation. The women entrepreneurs suggested that access to electricity and lack of business related physical capital/equipment deter their business start-up process. Around 9 per cent women entrepreneurs accept lack of physical capital as hindrance in starting-up business and around 7 percent reported that lack of electricity is impeding to start the business

Women entrepreneurs, up to now, mostly engaged in activities which mostly covers the women portion of the clientele. Around 22 per cent of women entrepreneurs reported that lack of relevant customers and high market competition create unfriendly environment against the neophyte women entrepreneurs.

Starting a business is challenging for a neophyte women. Any business requires some relevant technical knowledge. The knowledge can be gathered through attending various training program. But access to training program is not easy for all. The opportunity for business related training for women entrepreneurs is limited and from the survey we find that around 35 percent women entrepreneurs reported that the lack of training opportunity is impeding the business start-up process and on the other hand, around 21 per cent reported that lack of technical knowledge has impeded to be an entrepreneur.

Any business requires capital mostly comprised of own equity or credit. In a resource constrained society, especially in a society where the asset ownership of 
women, in general, is scanty, the demand for credit arises even among the micro entrepreneurs. The women entrepreneurs are not exceptional. The women entrepreneurs expressed that capital constraint is the major constraint to business start-up and access to credit is harshly present in the pave of their business development. Around 29 percent of the women entrepreneurs presumed that access to credit is limiting their business start-up. The problem is even intensified by the high interest rate (figure 4 ).

\subsection{The Growth Phase of Business: Growth Areas, Sources and Problems}

The constraints are not only present in start-up phase but also present in growth phase. The women entrepreneurs have on average 8 years business experience and many of the women entrepreneurs have experience over 20 years. In their phase of development, their businesses have expanded vertically and horizontally. The employment size, capital size, and monthly turnover have increased substantially. But their growth phase was not smooth and they faced various social, political, and economic impediment in their way of growth (figure 5).

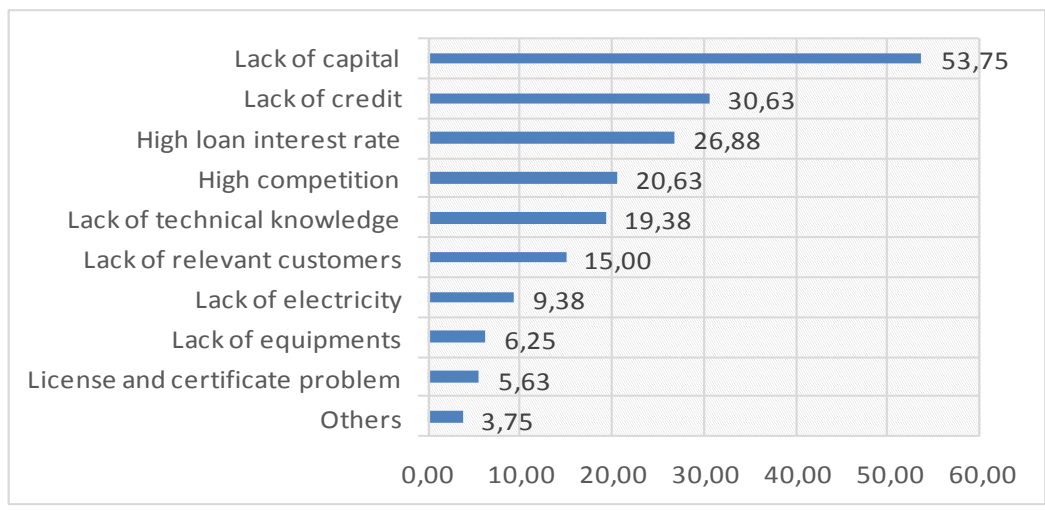

Figure 5. Business growth constraints

Source: Survey Data (2016)

Like the start-up impediments, women entrepreneurs face the homogenous constraints in their growth phase as well. For example, capital constraint and lack of access to credit was also prevalent in their growth stage. High loan interest rate discouraged to borrow and market competition sometime impeded their growth. Lack of technical knowledge like lack of knowledge about ICT tools and their usages hampered their business growth

\subsection{Econometric Result}

Before estimating the effect of credit constraint on sales performance, let start with the endogeneity between sales and size of the finance. The regression based endogeneity specification test result is reported in table 5 . 
Abdul KHALEQUE

Table 5. Regression based Durbin-Wu-Hausman endogeneity test

\begin{tabular}{|c|c|c|c|c|}
\hline \multirow{2}{*}{ Explanatory variables } & \multicolumn{2}{|c|}{ Credit equation } & \multicolumn{2}{|c|}{ Sales equation } \\
\hline & Coefficient & se & Coefficient & se \\
\hline Schooling of women entrepreneur & 0.111 & 0.105 & $-0.042 *$ & 0.025 \\
\hline Business experience & 0.091 & 0.071 & $0.112 * * *$ & 0.016 \\
\hline Training (yes=1, otherwise 0 ) & 0.689 & 1.152 & 0.070 & 0.283 \\
\hline Home is the business location (yes $=1$ ) & $-2.190 * *$ & 1.072 & $-1.076 * * *$ & 0.268 \\
\hline Organization is the client (yes $=1$ ) & $2.290 *$ & 1.193 & $0.619 * *$ & 0.308 \\
\hline $\begin{array}{l}\text { Lack of business related technical } \\
\text { knowledge (yes }=1 \text { ) }\end{array}$ & 0.514 & 1.247 & -0.379 & 0.292 \\
\hline Log of loan size & & & 0.064 & 0.041 \\
\hline Residuals & & & -0.001 & 0.046 \\
\hline Constant & $10.317^{* * *}$ & 1.974 & $10.262^{* * *}$ & 0.489 \\
\hline Model's statistics & & $=0.24$ & $R^{2}=0.45$ & \\
\hline
\end{tabular}

The t-statistics of the coefficient of the residuals of credit equation in the sales equation is -0.03 and the corresponding $P$ value and standard error are 0.98 and 0.046. All statistics about the coefficient of the residual suggests that the null hypothesis of exogeneity of credit variable is not rejected at any conventional level of significance. The result does not vary even if we use the robust variance, as suggested Cameron and Trivedi $(2005,276)$, in calculating the regression result and the endogeneity test result (table 5).

We find the Durbin-Wu-Hausman F-statistics, with a numerator degrees of freedom 1 and denominator degrees of freedom of 141, has a value of 0.0002 with a $p$-value of 0.99 and hence, the null hypothesis of the chosen variable is exogenous is not rejected. From both techniques, it can be said that the log of credit size in the log of sales equation is not endogenous rather it is exogenous.

Therefore, the OLS estimation of regression (17) will be consistent. Since the sample data is relatively small in size, sample fluctuation may hamper the estimates of the regression model. Therefore, alternate variances have been used to check the robustness of the findings. The OLS results are reported in the table 6.

The results are robust across various variance structure. The model is free of omitted variable bias as the Ramsey RESET test shows that the calculated F-value is only 1.04. Since the mean variance inflating factor (VIF) value is 1.56 , the model is also free of Multicollinearity problem. The model, however, is not free of heteroscedasticity the IMTEST of Cameron \& Trivedi and Breusch-Pagan test statistics confirms it.

However, correcting the heteroscedasticity problem by using the robust variance in estimating the OLS estimates, we obtain the result of last two columns of table (6). The result shows that nearly 52 per cent variation in log of sales is explained by the chosen set of explanatory variables and 48 per cent variation in log of sales is remained unexplained. The goodness of fit is statistically significant as the 
calculated F-value is a little over 10 whereas the critical F-value is expected to be below 4 considering the degrees of freedom and level of significance (table 6).

Table 6. OLS results for various standard errors

\begin{tabular}{|c|c|c|c|c|c|c|}
\hline \multirow{2}{*}{ Explanatory variables } & \multicolumn{2}{|c|}{ Standard OLS } & \multicolumn{2}{|c|}{ Bootstrap Model } & \multicolumn{2}{|c|}{ Robust Variance } \\
\hline & coef & se & coef & se & coef & se \\
\hline Log of loan size & $0.059 * * *$ & 0.020 & $0.059 * * *$ & 0.021 & $0.059 * * *$ & 0.022 \\
\hline Schooling of women entrepreneur & -0.039 & 0.024 & -0.039 & 0.024 & -0.039 & 0.027 \\
\hline Business experience & $0.083^{* * *}$ & 0.017 & $0.083^{* * *}$ & 0.020 & $0.083 * * *$ & 0.021 \\
\hline Training (yes=1, otherwise 0 ) & 0.057 & 0.279 & 0.057 & 0.238 & 0.057 & 0.276 \\
\hline Household size & $-0.201 * *$ & 0.089 & $-0.201 * *$ & 0.080 & $-0.201 * *$ & 0.085 \\
\hline Home is the business location (yes $=1$ ) & $-0.795 * * *$ & 0.257 & $-0.795 * * *$ & 0.207 & $-0.795^{* * *}$ & 0.240 \\
\hline Sell points (yes=1) & 0.229 & 0.264 & 0.229 & 0.296 & 0.229 & 0.308 \\
\hline Organization is the client (yes=1) & $0.558^{*}$ & 0.291 & 0.558 & 0.386 & 0.558 & 0.398 \\
\hline $\begin{array}{l}\text { Lack of business related technical } \\
\text { knowledge (yes=1) }\end{array}$ & -0.368 & 0.290 & $-0.368^{*}$ & 0.208 & -0.368 & 0.229 \\
\hline Constant & $10.715^{* * *}$ & 0.610 & $10.715^{* * *}$ & 0.550 & $10.715^{* * *}$ & 0.623 \\
\hline Model's statistics & \multicolumn{6}{|c|}{$\mathrm{F}(14,132)=10.02 R^{2}=0.52 ; \mathrm{N}=147$} \\
\hline $\begin{array}{l}\text { Ramsey RESET Omitted variable bias } \\
\text { test }\end{array}$ & \multicolumn{6}{|c|}{$F(3,129)=1.04$} \\
\hline Multicollinearity test & \multicolumn{6}{|c|}{ Mean VIF = 1.56} \\
\hline Breusch-Pagan test for heteroscedastic & \multicolumn{6}{|c|}{$\operatorname{chi} 2(1)=4.76$} \\
\hline
\end{tabular}

Note: ${ }^{* * *} p<0.01,{ }^{* *} p<0.05,{ }^{*} p<0.1$. The model includes divisional dummies to capture the divisional effect on sales performance. Source: Based on survey data (2016)

The result shows that for 1 per cent increase in availability of credit increases around 6 percent monthly sales, holding other things remaining the same and the increment in monthly sales due to 1 per cent increase in availability of credit is found statistically significant even at 1 per cent. Therefore, this result confirms that access to credit matters in increasing sales and thereby profit holding costs constant.

Besides access to credit, other variables also contribute in sales performance. For example, business experience has a positive effect on sales, that is, sales are higher for experienced entrepreneurs than the others which is rational. The result suggests that an addition 8.3 per cent sales gain is possible for an additional business experience holding other things constant. This relationship is also found significant at 1 per cent.

The effect of training on sales is found positive but this relationship is not found significant and the schooling of the entrepreneur is also found insignificant. Although the model is free of Multicollinearity problem, but pair-wise correlation may give such result.

Business location is the important determinant of sales. The result shows that there is a negative relationship between sales and home-based enterprises. The enterprise that is located at home has lower sale compared to the enterprises 
which are located to market and business place. This result is normal as the market place gives the larger market opportunities, the sales is expected to be high.

Business related lack of technical knowledge reduces the sales and this relationship is found significant at 10 per cent level in the bootstrapping regression model. In the other two models, the results are found in similar direction but not significant at even 10 percent level.

The model shows half of the regressions used in the model are significant at different significance level but half of the variables remain insignificant. But the variables which are insignificant in this model are seemed to be important variables from theory and orthodox believe. For example, human capital, the years of schooling has important role on business performance. Moreover, training of the entrepreneurs, sale points, and the clientele group is expected to have important effects on sales. As we have already come to a conclusion that the simple OLS model, albeit free from Multicollinearity and omitted variable bias, suffers from heteroscedasticity problem. The theoretical framework gives us the idea about sales are related to credit constraints and mostly related directly to credit size. Therefore, the heteroscedasticity is presumed to be directly proportional to credit size, i.e., $E\left(\epsilon^{2} \mid x\right)=\sigma_{\epsilon}^{2} C_{i}$ implying variability in sales increases with an increase in credit size. Since the loan size is, generally, positive, the error variance must be positive as required.

The weighted least square (WLS) estimates, the GLS estimates for correcting heteroscedasticity, are reported in table 7.

\section{Table 7. Results of weighted least squares}

\begin{tabular}{lll}
\hline Explanatory variable & \multicolumn{2}{l}{ WLS Estimates within service recipients } \\
\hline & Coefficient & Se \\
\hline Log of loan size & $0.347^{* *}$ & 0.154 \\
Schooling of women entrepreneur & 0.015 & 0.038 \\
Business experience & $0.077^{* * *}$ & 0.025 \\
Training (yes=1, otherwise 0) & $-0.691^{*}$ & 0.371 \\
Household size & $-0.246^{* *}$ & 0.124 \\
Home is the business location (yes=1) & $-0.892^{* * *}$ & 0.330 \\
Sell points (yes=1) & -0.457 & 0.298 \\
Organization is the client (yes=1) & $0.831^{* *}$ & 0.355 \\
Lack of business related technical knowledge (yes=1) & -0.000 & 0.359 \\
Constant & $7.786^{* * *}$ & 1.871 \\
& $\mathrm{~F}(15,60)=6.62$ \\
Model's Statistics & $\mathrm{R}-\mathrm{sq} .=0.6234 ;$ Adj. R-sq. $=0.5293$ \\
\end{tabular}

Note: ${ }^{* * *} p<0.01,{ }^{* *} p<0.05,{ }^{*} p<0.1$

The White's general test of heteroscedasticity suggests that the model, now, is free from heteroscedasticity problem as well. Therefore, the findings are unbiased and consistent. 


\section{Discussion, Summary and Conclusion}

The studies on 'finance and growth' suggest that finance matters for growth. There are micro evidences as well as macro evidences on the nexus between growth and finance. The entrepreneurs, the micro level agents, play important role in overall growth. Therefore, theoretically, the growth or performance of the entrepreneur is determined by entrepreneur's specific characteristics and external factors. In a resource constrained society, the performance of a borrowing entrepreneur can be different compared to the non-borrowing self-financed entrepreneurs. The financial intermediaries often use some instruments to ration out borrowers, partly or fully. Such exclusion by the financial intermediaries or even by self-exclusion may limit the growth and the performance of the entrepreneur.

This study has been carried out to know the nature and reasons of barriers in accessing credit facilities from private banks by women entrepreneurs. The findings of this study will be empirical evidences of the theoretical foundation of credit rationing and enterprise's performance. It will also give an overview of the barriers faced by the women entrepreneurs. The paper can practically contribute in the initiation of establishing women entrepreneur friendly policies or the expedition of current steps towards women entrepreneurships.

The study covers six Sadar Upazila of six divisional districts of Bangladesh. In total, 168 women entrepreneurs were interviewed through structured questionnaire. The survey shows that around 53 per cent women entrepreneurs have parlor or boutiques business and around 21 per cent have tailoring or fashion related business. Therefore, near about three-fourth of the women entrepreneurs are employed in major four activities: (i) parlor, (ii) boutiques, (iii) tailoring, and (iv) fashion. Majority of the women entrepreneurs have an age below 35 and the women entrepreneurs are mostly educated: over 88 per cent of women entrepreneurs has education level over grade 9 and around 12 per cent has education below SSC. Around 41.3 per cent women entrepreneurs has completed higher educations - honors/masters. The average schooling of women entrepreneurs is 12 .

Women entrepreneurs start their business not because of availability of credit but because of their own experiences. For example, around 36 per cent women told that they started their business due to their family business experience and 11 per cent has said that their previous job experience has helped them to start their business. Training institutes and financial institutes induced around 13 percent women to start the business. The business success of other women also forces the women to start a new business: around 28 per cent agreed upon this statement.

Near about 81 per cent women entrepreneur possesses trade license and 48 per cent women entrepreneur has own business TIN certificate. Around one-fifth of the women entrepreneur holds personal TIN and VAT certificates. Among the experienced women entrepreneur the possession of various business related 
license and certificates is high compared to the neophyte women entrepreneur. The initial and current capital structure of the neophyte women entrepreneur is almost same whereas the current capital size increased around 3 fold for women entrepreneurs having business experience of 3 to five years.

The study focuses on the nexus between credit-constraint and sales performance of the women entrepreneurs. Conceptually, credit constraints and sales revenue are two concepts: credit constraints are determined by the borrower characteristics, the demand side factors, and the characteristics of financial institutions, the supply side factors. On the other hand, sales revenue is determined by quantity of output produced and the market price whereas quantity of output is determined by the factors of production and their rewards like wage, rent, etc. Therefore, it is quite apprehended that the two concepts, credit constraint and sales, are endogenously determined and endogeneity will be present. But the econometric specification tests show that the credit constraints in this setting are exogenous and, therefore, the OLS estimates of the sales regression found consistent and unbiased.

The regression result shows that for 1 per cent increase in availability of credit increases around 6 percent monthly sales, holding other things remaining the same and the increment is found statistically significant even at 1 per cent. Therefore, this result confirms that access to credit matters in increasing sales and thereby profit holding costs constant. Besides access to credit, other variables also contribute in sales performance. For example, business experience has a positive effect on sales, that is, sales are higher for experienced entrepreneurs than the others which are rational. The result suggests that an addition 8.3 per cent sales gain is possible for an additional business experience holding other things constant. This relationship is also found significant at 1 per cent.

In a nutshell, the credit constraints and the size of credit affect the sales performance of the women entrepreneurs. The relaxation of credit constraint increases 6 per cent monthly turnover holding other things remaining same and so, it can be concluded that relaxing credit constraints of women entrepreneurs improves their sales performance and hence is expected to increase their standard of living.

\section{References}

Abdullah, M. (1996). Entrepreneurship development in light engineering industries in Bangladesh: problems and policies. Management Development, 25(3), 13-19.

Aghion, P., Fally, T., \& Scarpetta, S. (2007). Credit constraints as a barrier to the entry and post-entry growth of firms. Economic policy, 22 (52), 732-779. https://doi.org/10.1111/j.1468-0327.2007.00190.x

Ang, J. B. (2008). A survey of recent developments in the literature of finance and growth. Journal of economic Surveys, 22(3), 536-576. https://doi.org/10.1111/i.1467$\underline{6419.2007 .00542 . x}$ 
Anwar, M. U., \& Rashid, A. G. (2012). Female entrepreneurs.

Banerjee, A. V., \& Duflo, E. (2008). Do firms want to borrow more? Testing credit constraints using a directed lending program.

Becchetti, L., \& Trovato, G. (2002). The determinants of growth for small and medium sized firms. The role of the availability of external finance. Small Business Economics, 19(4), 291306. https://doi.org/10.1023/A:1019678429111

Beck, T., Demirguc-Kunt, A., Laeven, L., \& Levine, R. (2004). Finance, firm size, and growth, National Bureau of Economic Research, No. w10983.

Binks, M. R., \& Ennew, C. T. (1996). Growing firms and the credit constraint. Small Business Economics, 8(1), 17-25. https://doi.org/10.1007/BF00391972

Bruton, G. D., Ketchen, D. J., \& Ireland, R. D. (2013). Entrepreneurship as a solution to poverty. Journal of Business Venturing, 28(6), 683-689. https://doi.org/10.1016/i.jbusvent.2013.05.002

BWCCI (2011). Building women in business: a situation analysis of women entrepreneurs in Bangladesh,

Cameron, A. C. \& P. K. Trivedi. 2005. Microeconometrics: Methods and Applications. New York: Cambridge University Press. https://doi.org/10.1017/CBO9780511811241

Carpenter, R. E., \& Petersen, B. C. (2002). Is the growth of small firms constrained by internal finance?. Review of Economics and statistics, 84(2), 298-309. https://doi.org/10.1162/003465302317411541

Carter S. (2000) 'Gender and Enterprise' in Carter S. and Jones Evans D. (eds) 'Enterprise and Small Business: Principles, Practice and Policy', Addison Wesley https://doi.org/10.1080/08985629800000013

Carter S. \& Rosa P. (1998) 'The financing of male- and female-owned businesses' Entrepreneurship and Regional Development, 10(3), 225-241

Carter, N.M., Gartner, W.B., Shaver, K. G. \& Gatewood, E.J. 2003. The career reasons of nascent entrepreneurs. Journal of Business Venturing 18, 13-39.

Cecchetti, S. G., \& Kharroubi, E. (2012). Reassessing the impact of finance on growth.

Celebioglu, F. (2017). Women Employment in terms of Gender Inequality across the Provinces of Turkey, Eurasian Journal of Business and Economics, Vol. 10, No. 19, pp. 61-80. https://doi.org/10.17015/ejbe.2017.019.04

Chan, R. C. (2010). A Working Capital Theory of the Firm with Empirical Evidence (Doctoral dissertation, University of Oxford).

Cull, R., \& Xu, L. C. (2005). Institutions, ownership, and finance: the determinants of profit reinvestment among Chinese firms. Journal of Financial Economics, 77(1), 117-146. https://doi.org/10.1016/j.jfineco.2004.05.010

De Bruin, A., Brush, C. \& Welter, F. (2007). Advancing a Framework for Coherent Research on Women"s Entrepreneurship. Entrepreneurship Theory and Practice, 31(3), 323-39. https://doi.org/10.1111/j.1540-6520.2007.00176.x

De Nardi, M., \& Villamil, A. (2009). Entrepreneurship, finance and employment. Annals of Finance, 5(3), 289-293. https://doi.org/10.1007/s10436-009-0124-z

Deidda, L., \& Fattouh, B. (2002). Non-linearity between finance and growth. Economics Letters, 74(3), 339-345. 
Demirgüç-Kunt, A., Beck, T., \& Honohan, P. (2008). Finance for all?: Policies and Pitfalls in Expanding Access. World bank.

Dinc, M. S. \& Budic, S. (2016). The Impact of Personal Attitude, Subjective Norm, and Perceived Behavioural Control on Entrepreneurial Intentions of Women, Eurasian Journal of Business and Economics, 9(17), 23-35. https://doi.org/10.17015/ejbe.2016.017.02

Dzisi, S. (2008). Entrepreneurial activities of indigenous African women: A case of Ghana. Journal of Enterprising Communities: People and Places in the Global Economy, 2(3), 254-264.

Farr-Wharton, R. \& Brunetto, Y. (2007). Women Entrepreneurs, Opportunity Recognition and Government-Sponsored Business Networks: A Social Capital Perspective. Women in Management Review, 22(3), 187-207. https://doi.org/10.1108/09649420710743653

Fay, M., \& Williams, L. (1991). Sex of applicant and the availability of business "start-up" finance. Australian Journal of Management, 16(1), 65-72. https://doi.org/10.1177/031289629101600104

Francis, A., Nassar, A., \& Mehta, K. (2013). Are we formal yet? The evolving role of informal lending mechanisms to support entrepreneurship and poverty alleviation in central Kenya. International Journal of Social Entrepreneurship and Innovation, 2(2), 109-129. https://doi.org/10.1504/IJSEl.2013.054152

Gielnik, M. M., \& Frese, M. (2013). Entrepreneurship and poverty reduction: Applying IO psychology to microbusiness and entrepreneurship in developing countries. Using IndustrialOrganizational Psychology for the Greater Good: Helping Those Who Help Others, 394-438.

Gore, C. (2001). The rise and fall of the Washington Consensus as a paradigm for developing countries. World development, 28(5), 789-804.

Guariglia, A., Liu, X., \& Song, L. (2011). Internal finance and growth: microeconometric evidence on Chinese firms. Journal of Development Economics, 96(1), 79-94. https://doi.org/10.1016/i.jdeveco.2010.07.003

Halkias, D., Nwajiuba, C., Harkiolakis, N. \& Caracatsanis S. M. (2011). Challenges Facing Women Entrepreneurs in Nigeria. Management Research Review, 34(2), 221-235

Harrison, P., Sussman, O., \& Zeira, J. (1999). Finance and growth: Theory and new evidence.

Hausman, J. A. (1978). Specification tests in econometrics. Econometrica 46, 1251-1271. https://doi.org/10.2307/1913827

Itani, H., Sidani, Y. M. \& Baalbaki, I. (2011). United Arab Emirates Female Entrepreneurs: Motivations and Frustrations. Equality Diversity and Inclusion: An International Journal, 30(5), 409-424. https://doi.org/10.1108/02610151111150654

Jamali, D. (2009). Constraints and Opportunities Facing Women Entrepreneurs in Developing Countries: A Relational Perspective. Gender in Management: An International Journal, 24 (4), 232-251. https://doi.org/10.1108/17542410910961532

Johnson, S. (2013). From microfinance to inclusive financial markets: the challenge of social regulation. Oxford Development Studies, 41(sup1), S35-S52.

King, K., \& McGrath, S. A. (Eds.). (1999). Enterprise in Africa: Between poverty and growth. London: Intermediate Technology. https://doi.org/10.3362/9781780440774

King, R. G., \& Levine, R. (1993). Finance and growth: Schumpeter might be right. The quarterly journal of economics, 717-737. https://doi.org/10.2307/2118406 
Levine, R. (2003). More on finance and growth: more finance, more growth?. Review-Federal Reserve Bank of Saint Louis 85(4), 31-46. https://doi.org/10.20955/r.85.31-46

Levine, R. (2005). Finance and growth: theory and evidence. Handbook of economic growth, 1, 865-934.

Manova, K. (2013). Credit constraints, heterogeneous firms, and international trade. The Review of Economic Studies, 80(2), 711-744. https://doi.org/10.1093/restud/rds036

Marlow, S., \& Patton, D. (2005). All credit to men? Entrepreneurship, finance, and gender. Entrepreneurship theory and practice, 29 (6), 717-735. https://doi.org/10.1111/j.15406520.2005.00105.x

McLymont, R. (2008). Wooing Women - Banks Roll Out Products with Gender Appeal, The Network Journal; Retrieved form http://www.thethomasyaccatogroup.ca/wooing.pdf, on February 10, 2012

Minetti, R., \& Zhu, S. C. (2011). Credit constraints and firm export: Microeconomic evidence from Italy. Journal of International Economics, 83 (2), 109-125. https://doi.org/10.1016/i.jinteco.2010.12.004

Mulira, F., Namatovu, R., \& Dawa, S. (2011). Panacea or Precipitate. "The Entrepreneurship and Poverty Paradox". Retrieved form http://www.academia.edu/download/16551727/mulira kenya.doc

Musso, P., \& Schiavo, S. (2008). The impact of financial constraints on firm survival and growth. Journal of Evolutionary Economics, 18(2), 135-149. https://doi.org/10.1007/s00191$\underline{007-0087-z}$

Mustafa, Z. \& Ismailov, N. (2008). Entrepreneurship and Microfinance: A Tool for Empowerment of Poor - Case of Akhuwat-Pakistan. Master's Thesis, School of Sustainable Development of Society and Technology, Malardalen University

Muûls, M. (2008). Exporters and credit constraints: A firm-level approach (No. 139). Brussels: National Bank of Belgium.

Nadgrodkiewicz, A. (2011). Empowering Women Entrepreneurs: The Impact of the 2006 Trade Organizations Ordinance in Pakistan. Center for International Private Enterprise; Retrieved form, on October 29 2011, http://www.cipe.org/publications/fs/pdf/042911.pdf

Nabi, K. A., \& Salahuddin, A. (1989). Entrepreneurship development in Bangladesh: A study of small non-mechanised leather footwear manufacturing units in Chittagong. The Chittagong University Studies, Commerce, 5, 173-184.

Pagano, M., \& Pica, G. (2012). Finance and employment. Economic Policy, 27(69), 5-55. https://doi.org/10.1111/j.1468-0327.2011.00276.x

Robinson, M. (2001). The microfinance revolution: Sustainable finance for the poor. World Bank Publications.

Roomi, M. A., Harrison, P. \& Beaumont-Kerridge. J. (2009). Women-Owned Small and Medium Enterprises in England: Analysis of Factors Influencing the Growth Process, Journal of Small Business and Enterprise Development, 16(2), 270-288. https://doi.org/10.1108/14626000910956056

Servon, L. J., \& Bates, T. (1998). Microenterprise as an exit route from poverty: Recommendations for programs and policy makers. Journal of Urban Affairs, 20(4), 419-441.

Siddiqui, S. (2003). Rural Entrepreneurship and Poverty Alleviation Programmes. YojanaDelhi, 47, 21-25. 
Abdul KHALEQUE

Stevenson, H. (1983). A Perspective on Entrepreneurship, Harvard Business School Press, Cambridge, MA.

The World Bank. (2001). World development report 2002: building institutions for markets. Oxford University Press.

Wu, D., M. (1974). Alternative tests of independence between stochastic regressors and disturbances: Finite sample results. Econometrica 42, 529-546. https://doi.org/10.2307/1911789 